\section{Coral bleaching in Jamaica}

SIR-Since early October 1989 , corals in Jamaican reefs have begun to lose their pigmentation (bleach). As in the 1987-88 bleaching event in the Caribbean ${ }^{1}$, all varieties of reef-building corals, ranging from the surface to more than $30 \mathrm{~m}$ depth, are affected. Repeated dives along the north coast of Jamaica and reports from divers indicate that the phenomenon is widespread, and that it began no earlier than late September.

As in the earlier event, bleached corals are common in all fore-reef waters, are relatively uncommon in the back-reef and are not confined to areas of unusual local environmental stress ${ }^{2}$. No new bleaching occurred in Jamaica in 1988, except for reefs just downcurrent from major river inflows, which were heavily bleached for about a month after large amounts of muddy freshwater runoff were dumped on them by hurricane Gilbert. Areas affected by the hurricane and those untouched by it are now bleaching.

Although the bleaching event still seems to be in its early stages, the overwhelming majority of corals are already affected. Many species have already completely lost their pigmentation, leaving areas of bleached white skeleton or tissue (for example Agaricia, Millepora and Palythoa species), some have preserved secondary screening pigments which make the colony appear unusual blue, green or pink colours (such as Siderastrea), whereas others have become very pale (such as most Montastrea, Diploria, Porites, Eusmilia, Dendrogyra, Meandrina and Erythropodium). Among the reefbuilding corals, only Madracis and Acropora seem minimally affected. Although the intensity of bleaching has not yet reached the greatest levels reached in late 1987, this year's event seems to be more widespread: Montastrea annularis colonies that bleached in 1987-88 are bleaching again, accompanied by pigment loss in colonies unaffected by the previous event. Many Jamaican genera (such as Agaricia, Siderastrea, Porites and Diploria) are much more strongly affected than by the previous episode.

As yet, there are no reports of bleaching elsewhere in the Caribbean (E. Williams, personal communication). It will be important to document whether the phenomenon is occurring in other parts of the region, as well as its onset and duration. Information should be sent to $\mathrm{Dr}$ Ernest Williams, Caribbean Aquatic Animal Health Project, Departamento de Ciencias Marinas, Universidad de Puerto Rico, PO Box 5000, Mayaguez, Puerto Rico, 00709.

The 1987-88 bleaching event began in late July, reached its peak around December and was largely complete by of the transcription process.
March 1988 (ref. 2). Maximum seawater temperatures in Jamaica are generally reached in October or November, but in 1987 temperatures rose early, and did not begin to fall until December. In October 1989 , ocean temperatures along the north coast of Jamaica were above $30^{\circ} \mathrm{C}$, and were at this level since at least early August. If bleaching is linked to a physiological reaction of corals and their symbiotic algae to elevated sea temperatures $^{3.4}$, the phenomenon could continue for at least a further month or two, depending on the time course of heat storage in Caribbean waters.

The 1987-88 bleaching episode raised concern of possible linkages between coral bleaching, rising tropical sea surface temperatures and the greenhouse effect, but its failure to appear in 1988-89 allowed the phenomenon to disappear from public awareness. Although it is too early to predict the ultimate severity or duration of the 1989 episode, there should be serious concern about its regional economic effects and global environmental implications.

During the nine months of the 1987-88 bleaching event, Caribbean reef-building

corals failed to grow ${ }^{2}$. Repetition of such events will alter the food chain of the coral-reef ecosystem, making corals less able to compete with rapid growth of fleshy algae. They could ultimately convert coral reefs into algal habitats, with severe economic losses from deterioration of reef fisheries, tourism and shore protection. Recent information suggests that the 1989-90 event has peaked and is concentrated in Jamaica. (Details of the distribution and course of the event are in preparation, Caribbean Research Community.)

Because Caribbean coral bleaching may be a visible warning of the early stages of global warming, there is a case for building now the means for monitoring the phenomenon of coral bleaching and the research capability for understanding its causes.

THOMAS J. GOREAU

Discovery Bay Marine Laboratory,

University of the West Indies,

\title{
Jamaica
}

\section{Received 23 October 1989}

1. Williams, E. H., Goenaga, C. \& Vicente, V. Science 238 , $877-878(1987)$

2. Goreau, T. J. \& Macfariane, A. H. Coral Reefs (in the press).

3. Hayes, R. L. Coral Reefs (in the press)

4. Sandeman, I. Proc. Ass. Island Marine Labs. Carib. 21, 50 (1988).

\section{Cryptic initiation sequence revealed}

SIR-Several groups ${ }^{1-3}$ have recently cloned the gene encoding the protein binding to the TATA box and known as TFIID. This protein plays a key role in the initiation of transcription by polymerase II by binding specifically to the canonical AT-rich element found in the promoter region of many eukaryotic genes. The cascade of reactions triggered by binding of TFIID to the TATA box ensures the accurate start

The nucleotide sequence of the TFIID gene corresponds to a protein of 240 amino acids with no strong sequence homology to any known polypeptide and

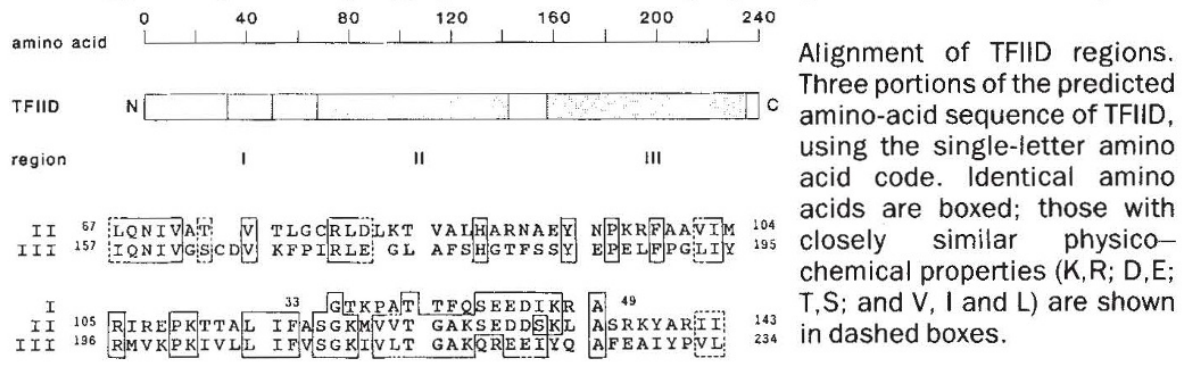

in which there are no obvious functional domains or highly conserved motifs. The significance of the weak similarity with parts of the prokaryotic sigma factor, which performs an analogous function in bacteria, is uncertain ${ }^{1-4}$.
But careful inspection of the TFIID amino-acid sequence reveals that a major portion of the protein is made up of two segments with clear homology with each other. Direct alignment (see figure) and matrix comparison (data not shown) show that the region from amino acid 67 to 143 (II in the figure) is very similar to the region (III in the figure) from amino acid 157 to 234 (35 per cent identity, 47 per cent strong homology). Moreover, the C-terminal regions of these repeats contains a region (amino acids 121 to 135 and amino acids 212 to 226 ) having less obvious but still significant homology with the N-terminal stretch of amino acids 33 to 49 ( $\mathrm{I}$ in the figure). Thus it seems that TFIID consists of a polypeptide repeated twice (or perhaps two and a half times).

$200 \quad 240$ tionary, structural and functional implications. TFIID from organisms now extant may have arisen by duplication of a primordial monomer, followed by sequence divergence. But the duplication 